\title{
Stabilizing Effects of a Particulate Demineralized Bone Matrix in the L4 Interbody Space with and without PEEK Cage - A Literature Review and Preliminary Results of a Cadaveric Biomechanical Study \\ C Bruce ${ }^{1}, \mathrm{KR}_{\mathrm{Chin}}{ }^{2}$, V Cumming ${ }^{3}$, NR Crawford ${ }^{4}$
}

\begin{abstract}
We reviewed the biological elements supporting the usefulness of a specifically designed particulate form of demineralized bone matrix (DBM) in spinal fusion, and report some limitations of its use described in the medical literature and in the interbody space using a cadaveric biomechanical model. A literature review and description of the techniques used to augment spinal fusion are presented, including a more thorough review of recent findings of cadaveric biomechanical flexibility studies using $D B M$ alone at different percentage fills of the existing disc space and DBM with a polyetheretherketone (PEEK) interbody cage. The need for DBM was established by reviewing limitations of autografts and allografts in spinal fusion. Demineralized bone matrix used alone did not increase stability post discectomy at L4-L5, but was demonstrated to exhibit satisfactory stability when used with a PEEK interbody cage. There may be a future role for DBM that hardens and fills disc space more rigidly, overcoming this limitation to its use.
\end{abstract}

Keywords: Augmentation of spinal fusion, cadaveric biomechanical flexibility study, particulate form demineralized bone matrix

\section{Estabilización de los Efectos de una Matriz Ósea Desmineralizada Particulada en el Espacio Intersomático a Nivel L4 con o Sin Cajetín PEEK: Revisión de la Literatura y Resultados Preliminares de un Estudio Biomecánico Cadavérico}

C Bruce ${ }^{1}, K_{R}$ Chin $^{2}$, V Cumming ${ }^{3}$, NR Crawford ${ }^{4}$

\begin{abstract}
RESUMEN
Examinamos los elementos biológicos que respaldan la utilidad de una forma particulada especificamente diseñada de matriz ósea desmineralizada (MOD) con fusión espinal. Asimismo reportamos algunas limitaciones de su uso en el espacio intersomático descritas en la literatura médica, mediante un modelo biomecánico cadavérico. Se presenta una revisión de la literatura, acompañada de una descripción de las técnicas utilizadas para aumentar la fusión espinal, incluyendo una revisión más exhaustiva de los hallazgos recientes de los estudios de flexibilidad biomecánico cadavérica, utilizando sólo MOD en diferentes rellenos de porcentajes del espacio discal existente, y $M O D$ con cajetines intervertebrales de polieteretercetona (PEEK). La necesidad de MOD se estableció examinando las limitaciones de los autoinjertos y los aloinjertos en la fusión espinal. El uso de la matriz ósea desmineralizada sola, no aumentaba la estabilidad post-disectómica a nivel L4-L5, pero se demostró que presentaba una estabilidad satisfactoria cuando se utilizaba con un cajetín intervertebral PEEK. Puede haber un papel futuro para un MOD que se endurezca y rellene el espacio del disco más rígidamente, venciendo así esta limitación a su uso.
\end{abstract}

\footnotetext{
${ }^{1}$ Department of Surgery, Radiology, Anaesthesia and Intensive Care, The University of the West Indies, Kingston 7, Jamaica, ${ }^{2}$ Charles E Schmidt College of Medicine at Florida Atlantic University and the Less Exposure Surgeons Surgery Institute (LESS Institute), Fort Lauderdale, FL, ${ }^{3}$ Less Exposure Surgery Society, Fort Lauderdale, FL and ${ }^{4}$ Barrow Neurological Institute, St Joseph's Hospital and Medical Center, Phoenix, AZ, USA.
}

Correspondence: Dr KR Chin, Less Exposure Surgeons Surgery Institute (LESS Institute), $1100 \mathrm{~W}$ Oakland Park Blvd, Suite \#3, Fort Lauderdale, FL, 33311, USA. E-mail: kingsleychin@gmail.com 
Palabras claves: Aumentación de la fusión espinal, estudio biomecánico cadavérico de la flexibilidad, matriz ósea desmineralizada en forma particulada

West Indian Med J 2013; 62 (8): 749

\section{INTRODUCTION}

A fusion procedure has become one of the most common means of treating spinal morbidities such as trauma, deformity and degenerative disc diseases. In recent times, the spinal fusion technique has been augmented with the use of autogenous bone grafting, but with the added complication of donor site morbidity and graft volume limitations, the pseudoarthrosis rates still range between five and $43 \%$ (1). Host risk factors such as smoking, osteoporosis and diabetes have also been implicated in increasing the rates of pseudoarthrosis in patients with spinal fusion. More recently, newer techniques, including the use of internal fixation devices, have been developed to increase fusion rates $(2,3)$. Despite these newer techniques, however, pseudoarthrosis rates remain persistently high (4-6). The consequences of pseudoarthoses include poor clinical outcomes and substantial medical expense. This has led to the development of newer techniques, osteosynthetic devices, and biological strategies to provide an alternative to autogenous bone grafting and to enhance and stimulate fusion.

\section{REVIEW}

The need for demineralized bone matrix

The biological processes involved in bone regeneration require three elements. These are: an osteogenic potential capable of directly providing cells to new bone being formed, osteo-inductive factors able to cause the osteoblastic differentiation of osteoprogenitor stem cells, and osteo-conductive scaffold facilitating neovascularization and supporting the ingrowth of bone. The ideal bone graft material possesses all of these three properties along with an optimal biological reaction and without risk of disease transmission. Autogenous bone grafts possess each of these three essential properties, and are thus considered the first choice for graft material in patients undergoing spinal fusion (7).

The autograft is not without complications. Autografts are associated with significant harvest site pain (8-14) persisting into the postoperative period. The invasiveness of an autogenous bone graft procedure is another concern.

Allografts provide another option for the stimulation of fusion in the human spine but provide minimal growth factors stimulating new bone growth, have exemplified poor incorporation, and adjacent tissue reactions are reported in some prospective studies (15-19). There are, however, other lower level evidence studies reporting acceptable rates of fusion when compared with autografts (20-25).

In an attempt to increase fusion rates and avoid significant morbidity associated with acquiring a graft, many bone substitutes have been developed. None of the existing bone substitutes exhibits all three of the principal elements in their present stages, however, some bone graft substitutes have shown some usefulness in basic and clinical studies. Research in progress in molecular biology has revealed new technologies for bone regeneration. Chiefly, with the improvements in regional gene therapy as well as in osteoinductive proteins and osteo-conductive carrier matrices, spinal fusion procedures are progressing into a new era of osteobiological technology.

Herewith, we aim to present a review of some of the biologic properties of a particulate form of demineralized bone matrix (DBM) [DBMPure, SpineFrontier Inc., Beverly, MA, USA], its usefulness, and discuss its limitations as have been determined thus far. All cadaveric specimens are received without any protected health information attached, so institutional review board approval is not required for cadaveric studies in the United States of America.

\section{Demineralized bone matrix}

Demineralized bone matrices (DBMs) are created by the acid excretion of allograft bone. The consequence is a loss of most of the mineralized component of bone, but they do give rise to type I collagen and noncollagenous proteins, including growth factors. This means that DBMs will lack structural strength but possess osteo-conductivity and osteo-inductive properties. The osteo-inductive ability in DBMs to stimulate bone regeneration is dependent upon the activity of the bone morphogenic proteins (BMPs). Demineralized bone matrix derived from human tissues is most likely to induce osteoinductive properties of bone and enhance fusion and bone growth (26-30). These materials include the osteo-inductive proteins of human bone and have the potential to aid with fusion.

Demineralized bone matrix may provide a very useful substitute to bone grafts promoting bony fusion because of the presence of growth factors making this substance easier to absorb (31-34). The particulate form of DBM is known to be easier to work with as it is easily packed into defect sites in bone without the need for operative planning or shaping prior to use (35).

Earlier studies of DBM and its usefulness have reported somewhat conflicting evidence of its usefulness in the clinical realm. An et al (19) reported that an allograft-DBM matrix yielded a higher rate of collapse and pseudoarthrosis in a prospective trial of allograft-DBM matrix versus autograft in anterior cervical spine fusion; while lower level evidence data report equal or similar performance of DBM used alone or to augment autografts in spinal fusion trials in the lumbar spine or with scoliosis $(9,23,36-39)$.

As aforementioned, DBMPure is created by the acid excretion of allograft bone. It is prepared as a micro- or 
macro-particle powder to be used as a packing material inside hollow metal cages, around polyetheretherketone (PEEK) cages, or on its own to fill disc or other space in the spine. Each of these uses presents challenges to the efficacy of DBM in clinical practice.

When DBM is used to pack metal cages in situ, there are concerns about introducing metal particulate effects from corrosion debris and phagocytosable particulate wear leading to particle-induced osteolysis after arthrodesis using metal implants and DBM. These effects, such as increased inflammatory response (cytokine mediated or increased expression of tumour necrosis factor-alpha), increased osteoclastic activity, or cellular apoptosis, are described in animal models (40-42) and in clinical review of patients presenting with spinal implant related pain (41). Another challenge when using DBM packed inside a metal cage is the lack of compression from bone to assist stimulating new bone growth. Bone necessitates compression to promote neovascularization and bone growth.

Demineralized bone matrix packing around PEEK cages is also practised to assist fusion with interbody use. Stress shielding is of concern with PEEK cages surrounded with DBM, but less so than DBM packing within the cage.

In our work, packing DBMPure around an Extraforaminal Lumbar Interbody Fusion Technology PEEK cage (ELIFT, SpineFrontier Inc.) after discectomy resulted in close results in range of motion as with the ELIFT alone post discectomy (43). As such, conclusions made in the aforementioned study suggest that the addition of DBMPure around a PEEK cage does not provide any additional stability during biomechanical flexibility testing. In our early studies of size of DBMPure particles and their ability to clump together to form a supporting base, we found no differences in stability when comparing the micro- and macro-particle sizes at $50 \%$ fill of the L4-L5 disc height (43).

The use of DBMPure alone to fill intervertebral space after discectomy was also examined in the abovementioned study. The effects of DBMPure at $100 \%$ fill of the disc space after discectomy were biomechanically similar to the discectomy state (43). The biomechanical data garnered demonstrated a loss of height with DBMPure packing alone and significantly increased range of motion during testing conditions. The experimenters also noted a pasty consistency of the DBMPure materials used, leading to a type of "toothpaste effect". To control this effect, plastic wrap was employed to limit the amount of DBMPure used during the experiment and help restrain and monitor the true fill effects based on real percentages of the disc space available for filling.

\section{CONCLUSION}

There remain many challenges to bone formation in spinal fusion as the indications and surgical practices continue to expand (44). We predict that the weaknesses of DBMPure may be overcome by efforts to increase the consistency of the product, thus allowing hardening of the paste, allowing it to fill disc space more rigidly. At this time, it seems that the biomechanical advantage of DBMPure in spinal fusion rests with its use in conjunction with PEEK interbodies and not alone at its current incarnation.

\section{ACKNOWLEDGMENTS}

This work was funded by the Less Exposure Surgery Society (LESSociety).

\section{Declaration of Interest}

KR Chin is employed by, is on the board of directors of, and has stock options in SpineFrontier Inc., C Bruce is on the Surgeon Advisory Board for SpineFrontier Inc., NR Crawford, at the Barrow Neurological Institute, has work funded by the Society of Facet Surgical Techniques and Technologies Inc. V Cumming has no disclosures.

\section{REFERENCES}

1. Cha CW, Boden SD. Gene therapy applications for spine fusion. Spine 2003; 28 (15 Suppl): S74-84.

2. Zhang JD, Poffyn B, Sys G, Uyttendaele D. Are stand-alone cages sufficient for anterior lumbar interbody fusion? Orthop Surg 2012; 4: 11-4.

3. Pradhan BB, Turner AW, Zatushevsky MA, Cornwall GB, Rajaee SS, Bae HW. Biomechanical analysis in a human cadaveric model of spinous process fixation with an interlaminar allograft spacer for lumbar spinal stenosis: laboratory investigation. J Neurosurgery Spine 2012; 16: 585-93.

4. Faundez AA, Schwender JD, Safriel Y, Gilbert TJ, Mehbod AA, Denis $\mathrm{F}$ et al. Clinical and radiological outcome of anterior-posterior fusion versus transforaminal lumbar interbody fusion for symptomatic disc degeneration: a retrospective comparative study of 133 patients. Eur Spine J 2009; 18: 203-11.

5. Bridwell KH, Sedgewick TA, O’Brien MF, Lenke LG, Baldus C. The role of fusion and instrumentation in the treatment of degenerative spondylolisthesis with spinal stenosis. J Spinal Dis 1993; 6: 461-72.

6. Zdeblick TA. A prospective, randomized study of lumbar fusion. Preliminary results. Spine 1993; 18: 983-91.

7. Epstein NE. Iliac crest autograft versus alternative constructs for anterior cervical spine surgery: pros, cons, and costs. Surg Neurol Int 2012; 3 (Suppl 3): S143-56. doi: 10.4103/2152-7806.98575. Epub 2012 Jul 17.

8. Younger EM, Chapman MW. Morbidity at bone graft donor sites. J Orthop Trauma 1989; 3: 192-5.

9. Price CT, Connolly JF, Carantzas AC, Ilyas I. Comparison of bone grafts for posterior spinal fusion in adolescent idiopathic scoliosis. Spine 2003; 28: 793-8.

10. Arrington ED, Smith WJ, Chambers HG, Bucknell AL, Davino NA. Complications of iliac crest bone graft harvesting. Clin Orthop Relat Res 1996; (329): 300-9.

11. Missiuna PC, Gandhi HS, Farrokhyar F, Harnett BE, Dore EM, Roberts B. Anatomically safe and minimally invasive transcrestal technique for procurement of autogenous cancellous bone graft from the mid-iliac crest. Can J Surg 2011; 54: 327-32. doi: 10.1503/cjs.028010.

12. Ahlmann E, Patzakis M, Roidis N, Shepherd L, Holtom P. Comparison of anterior and posterior iliac crest bone grafts in terms of harvest-site morbidity and functional outcomes. J Bone Joint Surg Am 2002; 84-A: 716-20.

13. Silber JS, Anderson DG, Daffner SD, Brislin BT, Leland JM, Hilibrand AS et al. Donor site morbidity after anterior iliac crest bone harvest for single-level anterior cervical discectomy and fusion. Spine 2003; 28: 134-9. 
14. Cabraja M, Kroppenstedt S. Bone grafting and substitutes in spine surgery. J Neurosurg Sci 2012; 56: 87-95.

15. Bishop RC, Moore KA, Hadley MN. Anterior cervical interbody fusion using autogeneic and allogeneic bone graft substrate: a prospective comparative analysis. J Neurosurg 1996; 85: 206-10.

16. Jorgenson SS, Lowe TG, France J, Sabin J. A prospective analysis of autograft versus allograft in posterolateral lumbar fusion in the same patient. A minimum of 1-year follow-up in 144 patients. Spine 1994; 19: $2048-53$.

17. An HS, Lynch K, Toth J. Prospective comparison of autograft vs. allograft for adult posterolateral lumbar spine fusion: differences among freeze-dried, frozen, and mixed grafts. J Spinal Disorders 1995; 8: 131-5.

18. Villavicencio AT, Babuska JM, Ashton A, Busch E, Roeca C, Nelson EL et al. Prospective randomized double blinded clinical study evaluating the correlation of clinical outcomes and cervical sagittal alignment. Neurosurgery 2011; 68: 1309-16; discussion 1316. doi: 10.1227/ NEU.0b013e31820b51f3.

19. An HS, Simpson JM, Glover JM, Stephany J. Comparison between allograft plus demineralized bone matrix versus autograft in anterior cervical fusion. A prospective multicenter study. Spine 1995; 20: 2211-6.

20. Young WF, Rosenwasser RH. An early comparative analysis of the use of fibular allograft versus autologous iliac crest graft for interbody fusion after anterior cervical discectomy. Spine 1993; 18: 1123-4.

21. Dodd CA, Fergusson CM, Freedman L, Houghton GR, Thomas D. Allograft versus autograft bone in scoliosis surgery. J Bone Joint Surg Br 1988; 70: 431-4.

22. Buttermann GR. Prospective nonrandomized comparison of an allograft with bone morphogenic protein versus an iliac-crest autograft in anterior cervical discectomy and fusion. Spine J 2008; 8: 426-35. Epub 2007 Mar 7.

23. Thalgott JS, Giuffre JM, Klezl Z, Timlin M. Anterior lumbar interbody fusion with titanium mesh cages, coralline hydroxyapatite, and demineralized bone matrix as part of a circumferential fusion. Spine J 2002; 2: 63-9.

24. Savolainen S, Usenius JP, Hernesniemi J. Iliac crest versus artificial bone grafts in 250 cervical fusions. Acta Neurochirurgica 1994; 129: $54-7$.

25. Miller LE, Block JE. Safety and effectiveness of bone allografts in anterior cervical discectomy and fusion surgery. Spine 2011; 36: 2045-50.

26. Chesmel KD, Branger J, Wertheim H, Scarborough N. Healing response to various forms of human demineralized bone matrix in athymic rat cranial defects. J Oral Maxillofac Surg 1998; 56: 857-63; discussion 64-5.

27. Cobos JA, Lindsey RW, Gugala Z. The cylindrical titanium mesh cage for treatment of a long bone segmental defect: description of a new technique and report of two cases. J Orthop Trauma 2000; 14: 54-9.

28. Edwards JT, Diegmann MH, Scarborough NL. Osteoinduction of human demineralized bone: characterization in a rat model. Clin Orthop Relat Res 1998; (357): 219-28.

29. Kado KE, Gambetta LA, Perlman MD. Uses of Grafton for reconstructive foot and ankle surgery. J Foot Ankle Surg 1996; 35: 59-66.
30. Russell J, Scarborough N, Chesmel K. Re: Ability of commercial demineralized freeze-dried bone allograft to induce new bone formation (1996;67:918-26). J Periodontol 1997; 68: 804-6.

31. Chen L, He Z, Chen B, Yang M, Zhao Y, Sun W et al. Loading of VEGF to the heparin cross-linked demineralized bone matrix improves vascularization of the scaffold. J Mater Sci Mater Med 2010; 21: 309 17. doi: 10.1007/s10856-009-3827-9. Epub 2009 Jul 26.

32. Gombotz WR, Pankey SC, Bouchard LS, Phan DH, Puolakkainen PA. Stimulation of bone healing by transforming growth factor-beta 1 released from polymeric or ceramic implants. J Appl Biomater 1994; 5: $141-50$.

33. Reddi AH, Cunningham NS. Recent progress in bone induction by osteogenin and bone morphogenetic proteins: challenges for biomechanical and tissue engineering. J Biomech Eng 1991; 113: 189-90.

34. Berven S, Tay BK, Kleinstueck FS, Bradford DS. Clinical applications of bone graft substitutes in spine surgery: consideration of mineralized and demineralized preparations and growth factor supplementation. Eur Spine J 2001; 10 (Suppl 2): S169-77.

35. Damien CJ, Parsons JR, Prewett AB, Rietveld DC, Zimmerman MC. Investigation of an organic delivery system for demineralized bone matrix in a delayed-healing cranial defect model. J Biomed Mater Res 1994; 28: 553-61.

36. Girardi FP, Cammisa FP Jr. The effect of bone graft extenders to enhance the performance of iliac crest bone grafts in instrumented lumbar spine fusion. Orthopedics 2003; 26 (Suppl 5): s545-8.

37. Sassard WR, Eidman DK, Gray PM, Block JE, Russo R, Russell JL et al. Augmenting local bone with Grafton demineralized bone matrix for posterolateral lumbar spine fusion: avoiding second site autologous bone harvest. Orthopedics 2000; 23: 1059-64; discussion 64-5.

38. Cammisa FP Jr, Lowery G, Garfin SR, Geisler FH, Klara PM, McGuire RA et al. Two-year fusion rate equivalency between Grafton DBM gel and autograft in posterolateral spine fusion: a prospective controlled trial employing a side-by-side comparison in the same patient. Spine (Phila Pa 1976) 2004; 29: 660-6.

39. Vaccaro AR, Stubbs HA, Block JE. Demineralized bone matrix composite grafting for posterolateral spinal fusion. Orthopedics 2007; 30: $567-70$.

40. Cunningham BW, Orbegoso CM, Dmitriev AE, Hallab NJ, Sefter JC, McAfee PC. The effect of titanium particulate on development and maintenance of a posterolateral spinal arthrodesis: an in vivo rabbit model. Spine 2002; 27: 1971-81.

41. Hallab NJ, Cunningham BW, Jacobs JJ. Spinal implant debris-induced osteolysis. Spine 2003; 28: S125-38.

42. Cunningham BW, Orbegoso CM, Dmitriev AE, Hallab NJ, Sefter JC, Asdourian $\mathrm{P}$ et al. The effect of spinal instrumentation particulate wear debris. An in vivo rabbit model and applied clinical study of retrieved instrumentation cases. Spine J 2003; 3: 19-32.

43. Chin KR, Perez-Orribo L, Rodriguez N, Reyes PM, Newcomb AGUS, Crawford NR. Final report: biomechanics of DBMPure as an interbody graft substitute or for interbody augmentation. final report. Beverly, MA, USA: Barrow Neurological Institute, Laboratory SBR; 2012 August 31.

44. Reid JJ, Johnson JS, Wang JC. Challenges to bone formation in spinal fusion. J Biomech 2011; 44: 213-20. 